\title{
Bacteriological Profile of Blood Culture from Adult Sepsis Patients from a Rural Based Tertiary Care and Teaching Hospital, Piparia, Vadodara, India
}

\author{
Radhika Khara* and Sucheta J. Lakhani
}

Department of Microbiology, SBKS MI \& RC, Piparia, Waghodia-391760, Gujarat, India

\section{Keywords}

Sepsis, Blood culture, Bacteria

\section{Article Info}

Accepted: 22 April 2018 Available Online: 10 May 2018

\section{A B S T R A C T}

In the last decade a number of tests were developed and used for early detection of sepsis yet blood culture remains a gold standard in establishing diagnosis of sepsis according to 1992-2001 definition which gives an emphasis on the role of microbes in the pathogenesis of sepsis. Thus this study was aimed at isolating and identifying bacterial and/or fungal agents from blood culture of the patients diagnosed clinically as having sepsis. A total of 673 blood cultures were performed from 743 patients and in the remaining patients microbes other than bacteria/fungi were found as cause of sepsis and so blood cultures were not performed in them. A total of 50.96\% (343/673) samples did not yield any bacterial/fungal growth whereas the rest $49.03 \%$ (330/673) showed growth with 339 isolates. The majority samples had single bacterial isolate i.e. 292 (88.48\%) whereas 12 $(3.64 \%)$ had polymicrobial i.e. $>1$ type of bacteria or bacteria plus fungus together from a single sample and 26 (7.90\%) samples had only fungal isolates. Also, of the 339 isolates, $51.32 \%$ (174/339) were Gram negative bacilli, 38.64\% (131/339) were Gram positive bacteria and $10.02 \%$ (34/339) Candida species. Klebsiella spp. - 19.46\% (66/339) was the most frequent isolate from blood culture followed by Staphylococcus aureus- $15.04 \%$ (51/339), CoNS- 14.45\% (49/339), E. coli 14.15\% (48/339), Candida species 10.02\% (34/339), Enterococcus species $7.37 \%$ (25/339), Acinetobacter species $7.96 \%$ (27/339), Salmonella species 4.42\% (15/339), Pseudomonas spp. 4.13\% (14/339) and a small percentage of each of Streptococcus pyogenes (4/339), Citrobacter freundii (2/339), Proteus spp. $(\mathrm{n}=1)$, an unidentified GNB (1/339) and contaminant GPR (2/339).

\section{Introduction}

The last decade witnessed the development and use of number of biomarker based tests for early detection of sepsis like procalcitonin, interleukin-6 (IL-6) etc. yet the blood culture remained a gold standard in establishing diagnosis of sepsis fulfilling the 1992-2001 definition which gave an emphasis on the role of microbes in the pathogenesis of sepsis using the term "suspected or proven infection" in the definition (Vincent, 2002; Nagoba et al., 2005; Bone et al., 1992).

Bacteria are a common cause of sepsis around the world and blood culture helps to isolate these and identify them as a cause of sepsis. Gram negative sepsis predominates over gram positive sepsis and also the proportion of Candida species has considerably increased in 
many institutions due to prolonged treatment with multiple antibiotics, the use of indwelling intravascular devices, and prolonged neutropenia in patients with cancer have been demonstrated to be independent risk factors for the acquisition of nosocomial candidemia (Reinhart et al., 2005).

This study was aimed at determining the bacteriological profile of clinically diagnosed sepsis patients in our setup.

The objectives of this study were to perform blood culture in clinically diagnosed sepsis adult patients and to isolate and identify the blood culture isolates obtained using standard biochemical tests.

\section{Materials and Methods}

This study was conducted in Clinical Microbiology Laboratory in Dhiraj Hospital under the Department of Microbiology from September 2012 to December 2015.

After obtaining ethical approval from the Institutional Ethical Committee.

A total of 743 patients with clinically diagnosed sepsis, with a proven/suspected infection and who fulfilled the inclusion criteria were included in the study.

Inclusion Criteria (Levy et al., 2003):

Adult patients (age $>18$ years) and having 2 or more of the following:

Temperature: $>38^{\circ} \mathrm{C}$ or $<36^{\circ} \mathrm{C}$

Tachypnea: $>20$ breaths/minute

Tachycardia: Heart rate $>90$ beats/minute Leukocyte count: $>12,000 / \mu 1$ or $<4000 / \mu 1$

Methods are described under the following headings: (Collee et al., 14 ${ }^{\text {th }}$ edn.; Betty A. Forbes et al., $12^{\text {th }}$ edn.; Koneman et al., $6^{\text {th }}$ edn).

\section{Collection}

For blood culture, blood samples were collected before administering antibiotics at our hospital. However, for patients referred from private hospitals, already treated with antibiotics, were still considered for blood culture and blood samples were collected before starting antibiotic in our setup.

Hence $5-7 \mathrm{ml}$ of blood sample was collected by venepuncture taking all aseptic precautions. For this a tourniquet was tied around the arm tightly and the patient was asked to make fist. The vein was palpated and located. Isopropyl alcohol $(70 \%)$ or Povidone Iodine $(10 \%)$ was applied with a help of sterile cotton over the cubital aspect of the forearm. Depending on the case, the samples were collected in BACTEC bottles (from BD Diagnostics - 30 $\mathrm{ml}$ of broth) or in commercially available conventional Monophasic Brain Heart Infusion (BHI) Broth bottles (HiMedia-70ml broth) and also in the Biphasic Medium (HiMedia) containing BHI broth $40 \mathrm{ml}$ and BHI slope 20ml. The BACTEC bottles (Figure 1) after collection were placed in BACTEC 9050 machine (Figure 2) while the Monophasic and Biphasic BHI (brain heart infusion) broth bottles (Figure 3 and 4) were placed in incubator at $37^{\circ} \mathrm{C}$ for 24 hours before processing.

\section{Processing}

The BACTEC bottles were removed only after the machine showed the sign of "positive/growth" or "negative/no growth" on its screen whereas in case of conventional monophasic and biphasic medium containing BHI broth subcultures were done on the next day.

Thus after the bottles were removed from machine/incubator direct smears were prepared and stained by Gram stain to detect 
presence of organism in the bottles and the reports of the smears were communicated to the clinician as early as possible. Thereafter the samples were sub-cultured on Mac Conkey's agar, Blood agar and also on Saboraud's Dextrose Agar (SDA) (all media from HiMedia) if fungal elements were seen on direct smear. Inoculated plates were incubated for $18-24$ hours at $37^{\circ} \mathrm{C}$. The plates were then observed for the formation of colonies. In case of biphasic medium, the bottle was tilted to allow the broth containing blood to flow over the surface of the slope and then kept in upright position in the incubator.

For the bottles showing no growth the BACTEC machine indicated negative result on the $5^{\text {th }}$ day. The specimens from these bottles were also subcultured to ensure that no organism is missed. After 24 hours if no growth was found on the plates, it was reported as negative i.e. "No Organism Isolated" finally on the $6^{\text {th }}$ day. In case of monophasic and biphasic medium bottles, 3 subcultures were done on alternate days before declaring as negative i.e. "No organism isolated."

\section{Identification}

All plates showing growth, either from BACTEC or conventional BHI bottles with monophasic or biphasic medium slopes, were subjected to identification using standard methods. The colony characters were observed and utilised for identification. The gram stained smears from colonies were observed for presumptive identification of colonies as gram negative bacilli colonies or gram positive cocci colonies.

For identification of gram positive cocci isolates, catalase, coagulase, mannitol salt agar test, bile esculin and bacitracin sensitivity were used whereas for gram negative isolates, catalase, oxidase, indole, methyl red, Voges-
Proskauer, citrate, urease, phenlypyruvic acid, motility, triple sugar iron test and sugar fermentation tests were carried out according to the standard methods (Collee et al., 14 ${ }^{\text {th }}$ edn.; Betty A. Forbes et al., $12^{\text {th }}$ edn.; Koneman et al., $6^{\text {th }}$ edn.).

\section{Results and Discussion}

A total of 743 patients diagnosed clinically as sepsis were included in the study from September 2012 to December 2015 (3 years 3 months). Of the total 743 patients, $61.50 \%$ (457/743) were male and $38.49 \%$ (286/743) were female patients. The mean age of the patients was 48.02 years.

A total of 673 blood cultures were performed and in rest the causes other than bacteria/fungi were established and so blood cultures were not performed. Of the total 673 blood samples cultured, 50.96\% (343/673) samples did not yield any bacterial/fungal growth whereas the rest $49.03 \%$ (330/673) showed growth.

A total of 339 isolates were obtained from 330 $(49.18 \%)$ blood culture positive samples. The majority samples had single bacterial isolate i.e. $292(88.48 \%)$ whereas $12(3.64 \%)$ had polymicrobial i.e.>1 type of bacteria or bacteria plus fungus together from a single sample and $26(7.90 \%)$ samples had only fungal isolates as shown in Chart 1.

Of the 339 isolates, $51.32 \%(174 / 339)$ were Gram negative bacilli, 38.64\% (131/339) were Gram positive bacteria and 10.02\% (34/339) Candida species. Predominantly Gram negative bacteria were isolated. In our study Klebseilla spp. - $19.46 \%$ (66/339) was the most frequent isolate from blood culture followed by Staphylococcus aureus - 15.04\% (51/339), CoNS- 14.45\% (49/339), E. coli $14.15 \%$ (48/339), Candida species $10.02 \%$ (34/339), Enterococcus species $7.37 \%$ (25/339), Acinetobacter species $7.96 \%$ 
(27/339), Pseudomonas spp. 4.13\% (14/339) and a small percentage of each of Streptoccus pyogenes (4/339), Citrobacter freundii (2/339), Proteus spp. $(\mathrm{n}=1)$, an unidentified GNB (1/339) and contaminant GPR (2/339) as shown (in the Chart 2) below. The blood culture isolates also included 15 Salmonella species contributing to $4.42 \%$ of the total number of blood culture isolates. Amongst Salmonella species $(\mathrm{n}=15), S$. typhi were more common i.e. $\mathrm{n}=12$ followed by $S$. paratyphi A $(\mathrm{n}=2)$ and $S$. paratyphi $\mathrm{B}(\mathrm{n}=12)$.

As shown in the Table 1, our findings in terms of culture positive findings (49.0\%) are compared to studies from other regions of India are higher. This could be because of the coordinated efforts of the consultants in ICU and the Clinical Microbiology Laboratory, proper sample collection and timely processing of the samples.

Chart.1 Types of Isolates obtained from blood culture positive specimens ( $\mathrm{n}=330)$

\section{Types of Blood Culture Isolates}

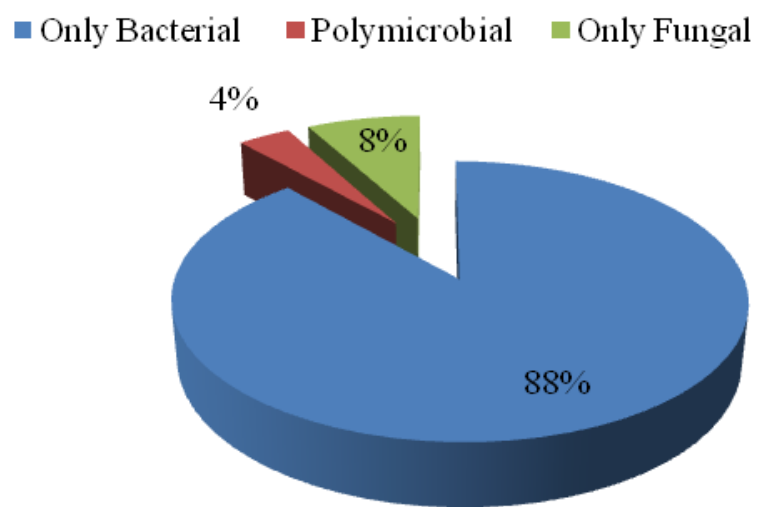

Chart.2 Number \& Type of Isolates $(\mathrm{n}=339)$ Obtained from Blood Culture Positive Specimens $(\mathrm{n}=330)$

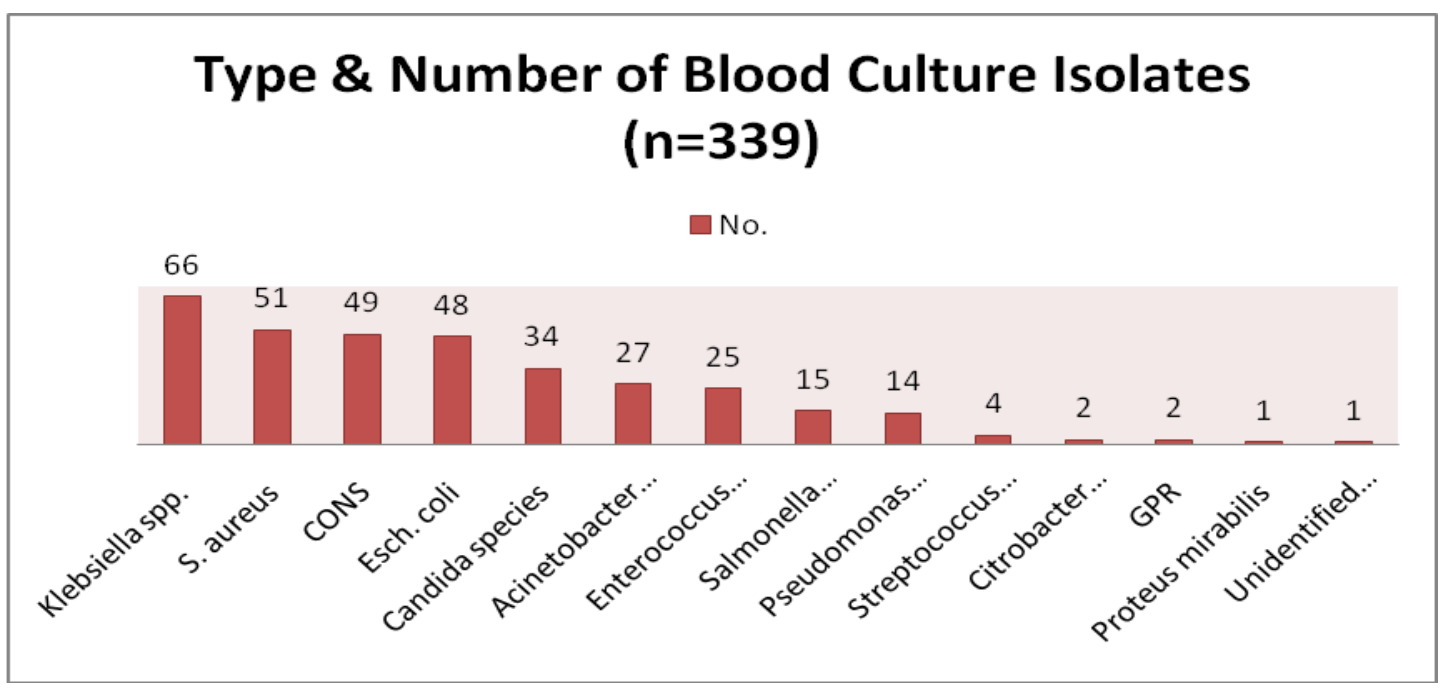


Table.1 Comparison of blood culture outcomes and isolate types with other studies

\begin{tabular}{|c|c|c|c|}
\hline Author & Place & $\begin{array}{c}\text { Positive Blood } \\
\text { Culture Outcome }(\%) \\
\text { and Isolate types }(\%)\end{array}$ & Frequent Isolates (\%) \\
\hline $\begin{array}{l}\text { Kante Meenakshi et al., } \\
2014 .\end{array}$ & $\begin{array}{l}\text { Andhra Pradesh, South } \\
\text { India }\end{array}$ & $\begin{array}{l}\text { Outcome }-17 \% \\
\text { Gram negative }-23 / 34 \\
(67.64 \%) \\
\text { Gram positive }-11 / 34 \\
(32.36 \%)\end{array}$ & $\begin{array}{l}\text { Pseudomonas aeruginosa } \\
(6.6 \%) \\
\text { S. aureus }(4.5 \%) \\
\text { Acinetobacter spp. }(6.6 \%) \\
\text { Klebsiella pneumoniae } \\
(2 \%) \\
\text { CoNS }(1 \%)\end{array}$ \\
\hline Abrahamsen et al., 2013. & Tamil Nadu, South India & $\begin{array}{l}\text { Outcome }-7 \% \\
\text { Gram negative - } \\
42.85 \% \\
\text { Gram positive }-19.04 \%\end{array}$ & $\begin{array}{l}\text { E. coli }(14.3 \%) \\
\text { S. typhi/paratyphi }(14.3 \%) \\
\text { S. aureus }(9.5 \%) \\
\text { Klebsiella spp. }(4.8 \%) \\
\text { Enterococcus spp. }(4.8 \%) \\
\text { Strep. viridians }(4.8 \%) \\
\text { Unidentified GNB }(4.8 \%) \\
\text { Pseudomonas spp. }(0 \%) \\
\text { Acinetobacter spp. }(0 \%) \\
\text { Other }(38.1 \%) \\
\text { Fungi }(4.8 \%)\end{array}$ \\
\hline Sahoo et al., 2016. & Odisha, East India & \begin{tabular}{lll}
\multicolumn{2}{l}{ Outcome } & $-26 \%$ \\
Gram & negative & - \\
$69.23 \%$ & & \\
Gram & positive & - \\
$30.76 \%$ & &
\end{tabular} & $\begin{array}{l}\text { E. coli }(34.6 \%) \\
\text { Klebsiella spp. }(26.9 \%) \\
\text { S. aureus }(23.1 \%) \\
\text { A. baumanii }(7.7 \%) \\
\text { CoNS }(7.7 \%)\end{array}$ \\
\hline Gupta et al., 2016. & New Delhi, North India & 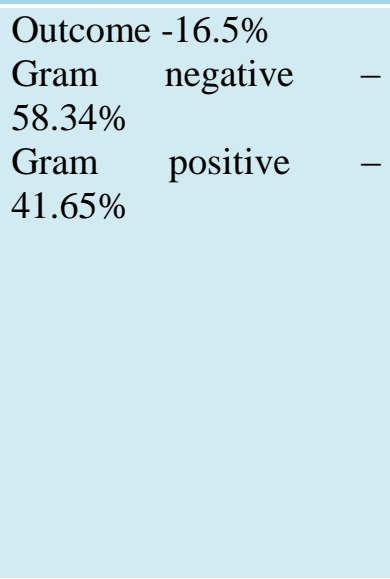 & $\begin{array}{l}\text { E. coli }(22.4 \%) \\
\text { Klebsiella spp. }(19.7 \%) \\
\text { S. aurues }(18.3 \%) \\
\text { CoNS }(17.4 \%) \\
\text { Pseudomonas } \\
(8.40 \%) \\
\text { Acinetobacter } \\
(5.20 \%) \\
\text { Enterococcus spp. }(4.8 \%) \\
\text { Streptococcus spp. }(4.8 \%) \\
\text { S. typhi }(1 \%) \\
\text { Citrobacter spp. }(0.9 \%) \\
\text { Proteus spp. }(0.35 \%)\end{array}$ \\
\hline Sonawane J et al., 2016. & $\begin{array}{l}\text { Navi Mumbai, West } \\
\text { India }\end{array}$ & $\begin{array}{ll}\text { Outcome } & 10.29 \% \\
\text { Gram } & \text { negative } \\
83.22 \% & \\
\text { Gram } & \text { positive } \\
16.78 \% & \end{array}$ & $\begin{array}{l}\text { Klebsiella spp. }(22.38 \%) \\
\text { Pseudomonas spp. } \\
(20.98 \%) \\
\text { Acinetobacter } \\
(17.48 \%) \\
\text { E. coli }(11.19 \%) \\
\text { S. typhi }(7.70 \%) \\
\text { Enterococcus spp. }(7.70 \%) \\
\text { S. aureus }(6.99 \%)\end{array}$ \\
\hline
\end{tabular}




\begin{tabular}{|c|c|c|c|c|}
\hline & & & & $\begin{array}{l}\text { Enterobacter spp. }(3.50 \%) \\
\text { Strep. spp. }(2.10 \%)\end{array}$ \\
\hline Oza S et al., 2016. & Surendranagar, Gujarat & $\begin{array}{ll}\text { Outcome } & 18.62 \% \\
\text { Gram } & \text { negative } \\
67.40 \% & \\
\text { Gram } & \text { positive } \\
32.60 \% & \end{array}$ & - & $\begin{array}{l}\text { K. pneumoniae (34.78\%) } \\
\text { CoNS }(15.22 \%) \\
\text { Pseudomonas } \\
(10.87 \%) \\
\text { E. coli }(8.69 \%) \\
\text { S. typhi }(4.35 \%) \\
\text { Enterococcus spp. }(4.35 \%) \\
\text { Acinetobacter } \\
\text { (4.35\%) } \\
\text { Unidentified GNB }(4.35 \%) \\
\text { Strep. spp. }(2.17 \%)\end{array}$ \\
\hline 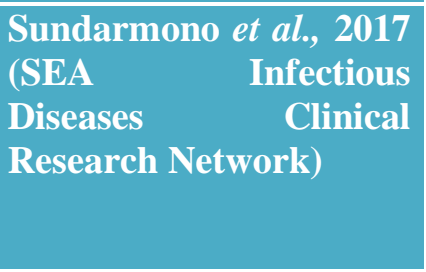 & South East Asia Region & $\begin{array}{l}\text { Outcome } \\
\text { adults) }\end{array}$ & (in & $\begin{array}{l}\text { E. coli }(5 \%) \\
\text { S. typhi }(0.2 \%) \\
\text { Acinetobacter spp. }(1 \%) \\
\text { Strep. suis }(1 \%) \\
\text { Burkholderia } \\
\text { pseudomallei }(<1 \%)\end{array}$ \\
\hline Lee et al., 2007. & North Carolina, USA & $\begin{array}{l}\text { Outcome } 73.1 \% \\
\text { (in first culture) }\end{array}$ & & $\begin{array}{l}\text { S. aureus }(20.70 \%) \\
\text { CoNS }(14.10 \%) \\
\text { Enterococcus spp. }(4.66 \%) \\
\text { Strep. spp. }(5.46 \%) \\
\text { K. pneumoniae }(9.55 \%) \\
\text { E. coli }(7.62 \%) \\
\text { Pseudomonas } \\
(4.43 \%) \\
\text { Yeasts }(8.64 \%)\end{array}$ \\
\hline Present Study & Vadodara, Gujarat & $\begin{array}{ll}\text { Outcome } & 49.03 \% \\
\text { Gram } & \text { negative } \\
51.03 \% & \\
\text { Gram } & \text { positive } \\
38.64 \% & \end{array}$ & - & 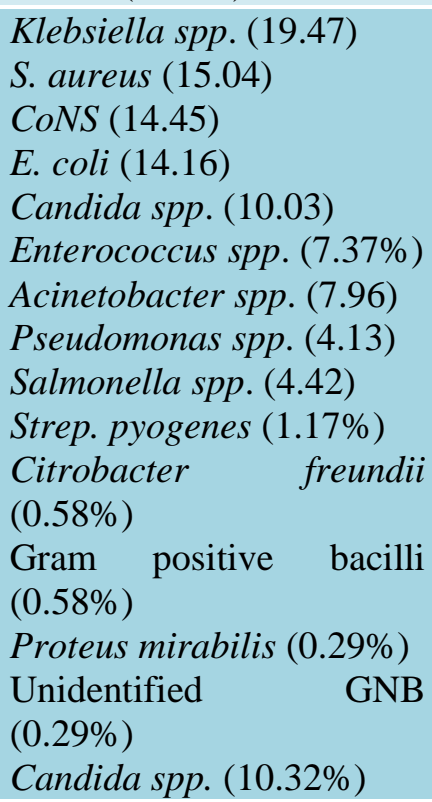 \\
\hline
\end{tabular}


Fig.1 BACTEC Aerobic Culture Bottle

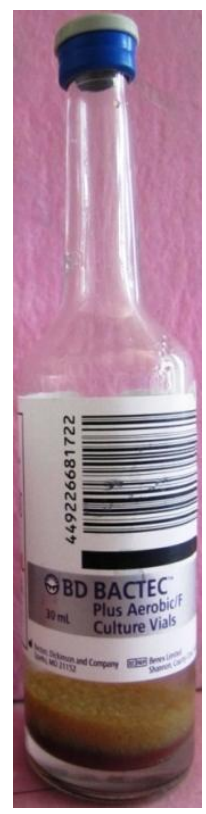

Fig.3 Biphasic Blood Culture Bottle

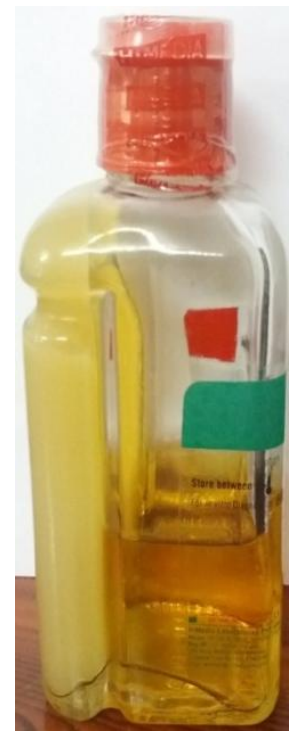

Septicaemia due to Gram negative bacteria predominated over Gram positive and these findings are comparable to those with other studies from India as well as other countries (Saravu et al., 2015; Divatia et al., 2016; Kante et al., 2014; Sahoo et al., 2016; Gupta et al., 2016; Sonawane et al., 2016; Oza et al., 2016; Jacob et al., 2009) but contrasting findings have been reported by Lee et al., (2007) and Kumalo et al., (2016) who
Fig.2 BACTEC 9050

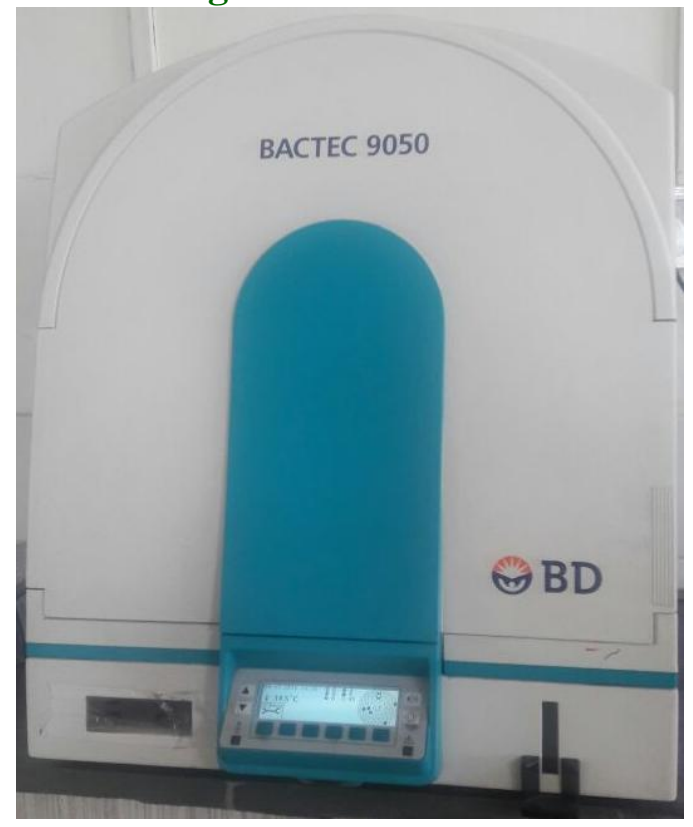

Fig.4 Biphasic Blood Culture Bottle

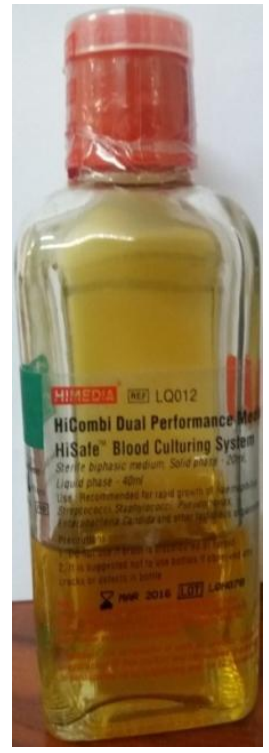

reported Gram positive cocci predominance with $52.33 \%$ and $53.3 \%$ respectively.

In our study Klebseilla spp. was the most frequent isolate from blood culture followed by Staphylococcus aureus, CoNS and E. coli. These findings are similar to Gupta et al., (2016) and Sonawane et al., (2016). Whereas in the other studies, Klebsiella pneumoniae (Oza et al., 2016), Staphylococcus aureus 
(Lee et al., 2007 and Kumalo et al., 2016), E. coli (Sahoo et al., 2016 and Gupta et al., 2016) and non-typhoidal Salmonella (Jacob et al., 2009) have been reported as the most frequent isolates from blood culture samples.

In our study we found $4.42 \% \quad(15 / 339)$ Salmonella species obtained from blood cultures of patients. Our findings in regards to isolation of Salmonella species are more than $1 \%$ and $0.2 \%$ reported by Abrahamsen et al., 2013 and South East Asia Region study by Sudarmono et al., (2017) respectively but lesser than $8 \%$ reported by Chrispal et al., (2010). Ugas et al., (2016) reports a case of septic shock with acute respiratory distress syndrome due to Salmnella typhi from Oklahoma, USA, which was found to be susceptible to ceftriaxone, cotrimoxazole and ciprofloxacin. Another case report from New Delhi, India by Randhawa et al., (2007), reports Salmonella paratyphi A, susceptible to Cefotaxime, Ciprofloxacin, Gentamicin, Amikacin and Cotrimoxazole which is similar to the findings of our.

CoNS was the third most common blood culture isolate i.e. $(n=49) 14.45 \%$ as well as the second most common gram positive cocci. Only single blood cultures were performed except for patients who had suspected endocarditis, where more than one blood cultures were obtained from different sites. Most of the studies consider it as a contaminant (Sudarmono et al., 2017) but as these have been isolated from critically ill patients admitted in ICU with clinically diagnosed sepsis these isolates were considered to be pathogenic rather than contamination. S Singh et al., 2016 used correlation with clinical parameters like temperature $>38^{0} \mathrm{C}$ or $<36^{\circ} \mathrm{C}$, systolic blood pressure of $<90 \mathrm{~mm} / \mathrm{Hg}$, total leukocyte count $>12,000 / \mu 1$ or $<4000 / \mu 1$ and presence of $>10 \%$ immature bands for establishing the significance of CoNS isolated from single cultures. In our study these clinical parameters are already fulfilled under sepsis definition. Thus with the same concept these were all considered significant. Also Oza et al., (2016) and Kumalo et al., (2016) report $13.3 \%$ CoNS being the second most common isolates from blood culture. Kumalo et al., (2016) suggests that though in past they were considered as non-pathogenic but currently due to increased use of indwelling medical devices they are on the rise.

Though the 1992-2001 definition gave importance to bacteria/fungi in the pathogenesis of sepsis, in February 2016 the Third International Consensus Definitions for Sepsis and Septic Shock defined sepsis as "life-threatening organ dysfunction caused by a dysregulated host response to infection" and the organ dysfunction in turn should be identified by bedside qSOFA (Quick Sequential Organ Failure Assessment) score of 2 points or more i.e. altered mental status, systolic blood pressure $\leq 100 \mathrm{~mm} \mathrm{Hg}$ or respiratory rate $\geq 22 / \mathrm{min}$ (Singer $\mathrm{M}$ et al., 2016). Thus the 2016 definition does not make any reference to the role of infection or microbes in sepsis. However, it is important to know the type of bacteria which helps to its pathogenesis, also helps clinicians choose right treatment when antimicrobial susceptibility results are made available to them and ways to prevent infections due to such microbes from spreading in the hospital. Overall the gram negative bacteria were commonly found as the cause of sepsis in our setup with Klebsiella spp. been the most common isolate and amongst gram positive cocci Staphylococcus aureus was the most common isolate. Moreover, though other bacteria like Streptococcus pyogenes, Citrobacter freundii and Proteus mirabilis were isolated in smaller percentage, yet they were found to be important cause of a serious condition like sepsis. 


\section{References}

Abrahamsen SK, Haugen CN, Rupali P, Mathai D, Langeland N, Elide GE et al., 2013. Fever in tropics: aetiology and case fatality - a prospective observational study in a tertiary care teaching hospital in South India. BMC Infectious Diseases, 13: 355.

Betty, A., Forbes, Daniel, F., Sahm, Alice, S., Weissfeld. Bailey \& Scott's Diagnostic Microbiology. 12lh Ed, 216-247

Bone RC, Balk RA, Cerra FB, Dellinger RP, Knaus WA et al., 1992. Definitions for sepsis and organ failure and guidelines for the use of innovative therapies in sepsis. Chest, 101(6): 1481-1483

Chrispal A, Boorugu H, Gopinath KG, Chandy S, Prakash JAJ, Thomas EM, et al., 2010. Acute undifferentiated febrile illness in adult hospitalized patients: the disease spectrum and diagnostic predictors - an experience from a tertiary care hospital in South India. Tropical Doctor, 40: 230-234.

Collee, J.G., Fraser, A.G., Marmion, B.P., Simmons, A. Mackie and McCartney Practical Medical Microbiology. 14th Ed.

Divatia JV, Amin PR, Ramakrishnan N, Kapadia FN, Todi S, Sahu S, et al., including all INDICAPS Study Investigators. 2016. Intensive Care in India: The Indian Intensive Care Case Mix and Practice Patterns Study. Indian J Crit Care Med [serial online], 20: 216

Gupta S, Kashyap B. 2016. Bacteriological profile and antibiogram of blood culture isolates from a tertiary care hospital of North India. Trop J Med Res; 19: 94-9.

Jacob ST, Moore CC, Banura P, Pinkerton R, Meya D, et al., (2009) Severe Sepsis in Two Ugandan Hospitals: a Prospective Observational Study of Management and Outcomes in A Predominantly
HIV-1 Infected Population. PLoS ONE 4(11): e7782.

Kante M, Uma P, John MS, Naidu MP. 2014. Bacterial profile of blood stream infections and antibiotic susceptibility pattern of isolates. Int $\mathbf{J}$ CurrMicrobiol App Sci, 3(12): 222-233.

Kumalo A, Kassa T, Mariam ZS, Daka D and Tadesse AH.2016.Bacterial Profile of Adult Sepsis and their antimicrobial Susceptibility Pattern at Jimma University Specialized Hospital, South West Ethiopia. Health Science J; 10 (2):

Lee A, Mirrett S, Reller LB, Weinstein MP. 2007. Detection of bloodstream infections in adults: How many blood cultures are needed? J Clin Microbiol; 45: 3546- 8.

Levy MM, Fink MP, Marshall JC, Abraham E, Angus D, Cook D, Cohen J, Opal SM, Vincent JL, Ramsay G. 2003. Society for Critical Care Medicine (SCCM) /European Society of Intensive Care Medicine (ESICM)/The American College of Chest Physicians (ACCP), the American Thoracic Society (ATS), and the Surgical Infection Society (SIS) International Sepsis Definitions Conference 2001. Intensive Care Med; (29): 530-538.

Nagoba BS. 2005. Clinical Microbiology. First Edition, BI Publications Pvt. Ltd

Oza SS, Mehta SJ, Kikani KM, Oza SG. 2016. Bacteriological profile and antibiogram of blood culture isolates from patients of rural tertiary care hospital. Indian $\mathbf{J}$ Microbiology \& Mycology; 4 (3):1-7.

Randhawa VS, Kumar A, Saili A, Datta V, Agrawal $C$ and Mehta G. 2007.Paratyphoid Sepsis. Indian J of Paediatr, 74 (2): 197-198.

Sahoo D, Mohanty L, Panda SS, Mishra SN. 2016. Bacteriological analysis of blood culture isolates in patients with sepsis in a tertiary care hospital of eastern India. 
International Journal of Contemporary Medical Research 2016; 3(12): 34483450 .

Saravu K, Prasad M, Eshwara VK, Mukhopadhyay C. 2015. Clinicomirobiological profile and outcomes of nosocomial sepsis in an Indian tertiary care hospital - a prospective cohort study. Pathogens and Global Health; 109(5): 228-235.

Singer M, Deutschman CS, Seymour CW, Shankarhari M, Annane D, Bauer M, et al., 2016. The Third International Consensus Definitions for Sepsis and Septic Shock. JAMA; 315(8): 801-810.

Sonawane J, Kamnath N, Shetty K, Swaminathan R. 2016. Bacteriological Profile and Antimicrobial Susceptibility Testing of Blood Culture Isolates from a Tertiary Care Hospital, Navi Mumbai. JMSCR; 4 (10): 13116-13124.

Sudarmono P, Aman AT, Arif M, Syarif AK, Kosasih H, Karyana M et al., 2017. Causes and outcomes of sepsis in South East Asia: a multinational and multicentre cross-sectional study by South East Asia Infectious Diseases Research Network. Lancet Global Health; 5: e157-67.
Ugas MB, Carroll T, Kova L and Susana Chavez-Bueno. 2016. Salmonella Typhi-induced Septic Shock and Acute Respiratory Distress Syndrome in a previously healthy teenage patient treated with high dose dexamethasone. J of Investig Med High Impact Case Rep.; 4(2): 1-5.

Vincent JL, Carlet J, Opal MS. 2002. The Sepsis Text - Chapter 1-Sepsis - The Magnitude of the Problem. Kluwer Academic Publishers; Springer Science \& Business Media; 2002.

Vincent JL, Ramsay G. 2005. Society for Critical Care Medicine (SCCM) /European Society of Intensive Care Medicine (ESICM)/The American College of Chest Physicians (ACCP), the American Thoracic Society (ATS), and the Surgical Infection Society (SIS) International Sepsis Definitions Conference 2001. Intensive Care Med; (29): 530-538.

Winn W, Allen S, Janda W, Koneman E, Procop G, Schreckenberger P, et al., 2006. Koneman's Colour Atlas \& Textbook of Diagnostic Microbiology, $6^{\text {th }}$ Edition.

\section{How to cite this article:}

Radhika Khara and Sucheta J. Lakhani. 2018. Bacteriological Profile of Blood Culture from Adult Sepsis Patients from a Rural Based Tertiary Care and Teaching Hospital, Piparia, Vadodara, India. Int.J.Curr.Microbiol.App.Sci. 7(05): 3173-3182. doi: https://doi.org/10.20546/ijcmas.2018.705.371 